\title{
POETIC SEEING IN VISUAL ARTS AND THEOLOGY. AESTHETICS AS A SPIRITUAL AND LOVING GAZE WITHIN THE HUMAN QUEST FOR MEANING.
}

Author:

Prof D. J. Louw

\section{Affiliation:}

Faculty of Theology,

University of Stellenbosch, Stellenbosch 7600

\section{Correspondence to:}

Prof D. J. Louw

\section{Email:}

djl@sun.ac.za

Postal address:

171 Dorp Street,

Stellenbosch, 7600 , South

Africa

\section{Dates:}

Accepted: 01 Jun. 2015 Published: 01 Sep. 2015

\section{How to cite this article:}

Louw, D. J., 2015, 'Poetic Seeing in Visual Arts and Theology. Aesthetics as a Spiritual and Loving Gaze within the Human Quest for Meaning', KOERS - Bulletin for Christian Scholarship 80(1), Art. \#2207, 13 pages. http:// dx.doi.org/10.19108/ koers.80.1.2207

\section{Copyright:}

(c) 2015. The Author(s) Published under the Creative Commons Atribution License.
A human being is essentially homo aestheticus and not in the first place homo faber. In the light of this basic assumption, it is argued that, due to poetic seeing, interconnectedness between $\operatorname{art}^{1}$, spirituality and the human quest for meaning exists. It is virtually impossible to define art. However, in one way or another, art is connected to imagination, inspiration and creativity. Art probes into the realm of the unseen, thus the value of iconic seeing in visual arts. By means of art, objects are moved into imagination and connected to the 'idea' beyond the vision of phenomenological observation. Serious art probes into the dimension of the unseen; it makes the invisible, visible. Art deals inter alia with 'signals of transcendence' (Peter Berger) ${ }^{2}$ and opens up new avenues for religious thinking and spiritual experiences. Serious art can thus contribute to the healing dimension of spiritual wholeness. Art can even assist theology in the reframing of existing God-images. In this regard, the notions of a Compassionate God and God as Covenantal Partner for Life, become appropriate alternatives for the imperialistic pantokrator-images (omnicategories) of theism.

Keywords: homo aestheticus, visual arts, poetic seeing, meaning in suffering, aesthetics, imagination, theology and God-images, theopascitism.

Die mens is wesenlik homo aestheticus en nie in die eerste plek homo faber nie. In die lig van die estetiese funksie van 'n poëtiese skoue kan 'n netwerkverband tussen kuns, spiritualiteit en die mens se soeke na sin voorveronderstel word. Dit is basies onmoontlik om kuns finaal te definieer. Tog het kuns op een of ander manier te doen met 'ver-beeld-ing', inspirasie en kreatiwiteit. Kuns dring die sfeer van die onsienlike binne en 'maak' op 'n skeppende wyse die onsienlike in objekte en visuele waarneming, sigbaar; dit werk heuristies en kreatief-ontdekkend; dit penetreer die sogenaamde 'idee' agter dit wat mens in die fenomenologie van waarneming 'sien'. Kuns is in ' $\mathrm{n}$ sekere sin ikonies en staan in verband met transendensie. Kuns breek brute werklikheid oop en is ' $n$ soort van venster vir sinvolle spirituele ervaringe en religieuse denke. Ernstige kuns kan beskou word as ' $n$ vorm van heling op die vlak van 'spirituele gesondheid' (wholeness). Die basiese hipotese is dat die visuele kunste teologie kan help om bestaande, geykte vorme van teologisering, te transformeer. So byvoorbeeld kan die imperialistiese pantokrator-idee van'n 'onveranderlike, teïstiese God' (omni-kategorie) deur middel van religieuse estetika verskuif na die sensitiewe 'Mee-lydende God' (patos-kategorie): God nie as kousaliteitsbeginsel nie maar as Lewende Verbondspartner.

Trefwoorde: homo aestheticus, visuele kunste, poëtiese skoue, sin in lyding, estetika, verbeelding, teologie en Godskonsepte, teopasgitisme.
1 There are different levels and dimensions of art. The article focuses on the visual arts, although the principles of

Peter Berger (1992:121) in A Far Glory: The Quest for Faith in an Age of Credulity. "In openness to the signals of transcendence the true proportions of our experience are rediscovered. This is the comic relief of redemption; it makes it possible for us to laugh and to play with a new fullness." Signals of transcendence create spiritual spaces for processes of hoping when life seems to be merely the tragedy of a cul de sac. 


\section{CAN ONE 'SEE' THE 'UNSEEN'?}

From merely an empirical, phenomenological and observational point of view, perhaps not. The empiricist only 'sees' what the senses experience factually.

From an aesthetic point of view, perhaps yes. The artist 'sees' more than the eye of the beholder can capture. "Of course, all art is to some extent an illusion. It transforms experience in order to satisfy some need of the imagination" (Clark 1974:191).

Thus, the following hypothesis: artistic viewing supersedes the limitations of merely phenomenological experiences and observation. Art probes into the fourth dimension of life (signals of transcendence) wherein time and space are transformed into a visual and spiritual togetherness that brings about a kind of integration (wholeness), spiritual fusion and interconnectedness between object and viewer. For this "spiritual interconnectedness" one needs imagination.

In 1992 Ellen Dissanyake wrote a book entitled Homo Aestheticus: Where Art comes from and Why. Her basic assumption is that art can be regarded as a natural general proclivity that manifests itself in culturally learned specifics such as dances, songs, performances, visual display and poetic speech. Art makes life special, because making art involves taking something out of its everyday and ordinary use context and making it somehow special - the ordinary becomes extraordinary. As meaning-maker, a human being is basically homo aestheticus and thus in essence an interpreter of 'signals of transcendence'.

According to K. Jaspers (1962), one can walk through life like a "wise fool", leaving behind signs (chiffre) which function as poetic images to be interpreted: ut pictura poesis ${ }^{3}$ (life as a poetic image).

Pictura poesis indicates that life is more than reasoning and seeing; life is poetic imaging; a silent poem to be interpreted. Applicable in this regard is the Ciceronian formula: poema loquens picture, pistura tacitum poema (poetry is a spoken painting; painting is a silent poem) (in Huyghe 1981: 20). Poetry is art and art is poetry: ut pictora poesis (literally 'as poetry, so painting').

As homo aestheticus there is an innate need in human beings for creative imagination; i.e. the making of transitional objects as means of overcoming loss and the limitations set by suffering and vulnerability. Our being human is intrinsically involved in the creative attempt to signify and decode the markings of life.

\section{Imagination: the aesthetics of iconic seeing}

To imagine is closely related to the art of seeing and the aesthetics of humane living.

The formula of Horace, in Huyghe 1981:20.

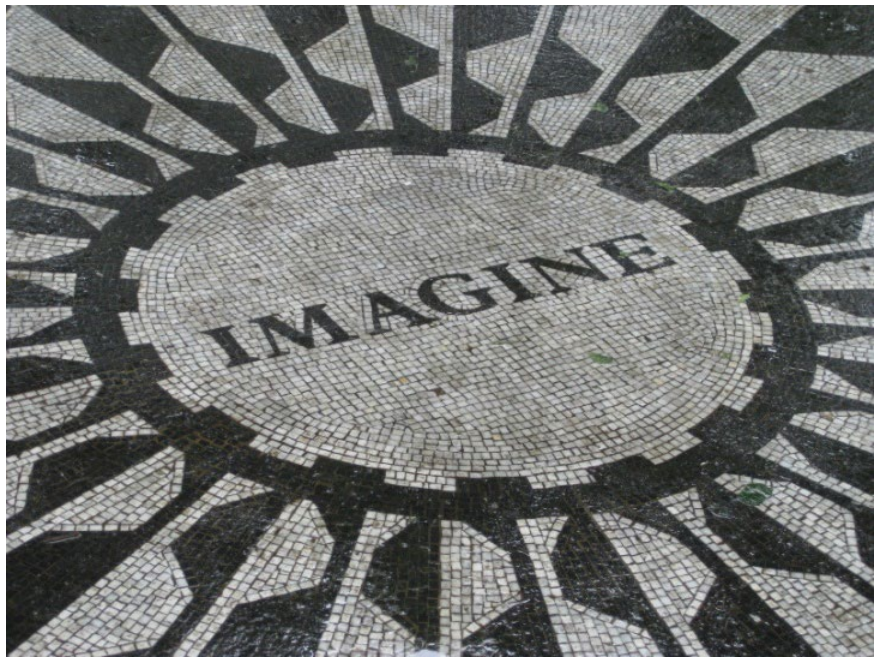

The John Lennon memorial, Central Park New York ${ }^{4}$ (Strawberry Fields) with title of his very famous song Imagine. Gift from Yoko Ono and City of Naples on what would have been Lennon's 45th birthday. Design from a Roman mosaic in Pompei (Pappalardo and Ciardiello 2012: 7). Authorized copyright, Central Park Conservancy (http://www.centralparknyc.org/visit/things-tosee/south-end/strawberry-fields.html. Accessed 05/01/2013)

In the now famous song Imagine, John Lennon dreamt about a different and, perhaps, better world.

\section{Imagine no possessions}

I wonder if you can

No need for greed or hunger

A brotherhood of man

Imagine all the people sharing all the world

John Lennon's song gained iconic status. It captured the imagination of a new x-generation, disillusioned by the artificiality and materialism of a capitalist society. Imagination helped him to 'see' more. It opened up the mind of youth to start imagining a new or different world.

It is perhaps true that one cannot say what true art is about. To define aesthetics is impossible. However, my hunch is that art hinges on the mystery of the human spirit, the yearning for freedom beyond the limitations of what already exists and has been achieved.

\footnotetext{
4 http://www.google.co.za/imgres?q=john+lennon+memorial\&num $=10 \& \mathrm{hl}=\mathrm{en} \& \mathrm{tbo}=\mathrm{d} \& \mathrm{biw}=1197 \& \mathrm{bih}=569 \& \mathrm{tbm}=\mathrm{is}-$ ch\&tbnid=Jе3UзpFEkAfxcM:\&imgrefurl=http://mildlymystical. com/2010/o3/\&docid=z48pXrjoHV1CZM\&imgurl=http://mildlymystical.com/wp-content/uploads/2010/03/Imagine-John-Lennon-Memorial_1.jpg\&w=800\&h=600\&ei=uEvnUNL5OIKKhQe-wYGIBQ\&zoom =1\&iact $=\mathrm{hc} \& v p \mathrm{x}=891 \& \mathrm{vpy}=257 \& \mathrm{dur}=10969 \& \mathrm{hovh}=1$ 94\&hovw=259\&tx=198\&ty=98\&sig=103342659865535404959\&pa ge=2\&tbnh=146\&tbnw=189\&start=18\&ndsp=22\&ved=1t:429,r:39,s: o,i:210. Accessed 05/01/2013.
} 
Perhaps, the reason why Beethoven cherished freedom and virtue? The subject rumbled through his mind so that finally Fidelio became "the greatest of all hymns to liberty, as the victims of injustice struggle up from their dungeons towards the light. 'O happiness to see the light,' they say, 'to feel the air and be once more alive. Our prison was a tomb. $\mathrm{O}$ freedom, freedom come to us again' “(Clark 1974: 305).

Is seems that one could indeed assume that art is inter alia the ability of the human spirit to transcend and supersede the limitations of observation and perception (the seen) by means of inspiration and imagination, establishing a kind of spiritual freedom. Art probes into the dimension of the unseen and presupposes the creativity of imagination.

By means of imagination and the symbolic value of images, the poetic gaze probes into the realm of the unseen. Thus, the reason why iconic viewing and most forms of arts, especially the visual arts, operate within the spiritual realm of life. Paintings and sculptures, images (eikon) are in essence aesthetic reflections of "eternal human values" probing into the realm of transcendence and meaning. The iconic gaze is thus an attempt to represent glimpses of "the Ultimate". One could say that art largely is iconic; poetic images giving birth to the sacred dimension of life.

\section{The chronotype approach: spiritual fusion}

By means of imagination and symbolisation, time, space, subjective experiences, and meaning, start to fuse with one another. This fusion of time and space, which transcends the limitations of three dimensions, can, in Einstein terminology, be called: chronotope 5 (Antonova 2010: 24). Time and space, the unseen and the seen, are fused into what one can call: seeing and imagining the "whole"; different levels and dimensions attached to an object become visible simultaneously. A chronotype-approach ${ }^{6}$ to life experiences brings about a kind of spiritual synthetics or fusion that can overcome and

In the philosophy of language and philology, chronotope is a term coined by M.M. Bakhtin to describe the way time and space are described by language. The term itself (Russian: Хронотоп), from Greek: time (хро́voc) and space (то́тос) can be literally translated as "time-space." The term describes the intrinsic connectedness of temporal and spatial relationships that are artistically expressed in literature. Artistic chronotope describes the fact that spatial and temporal indicators are fused into one carefully thought-out, concrete whole.

Chronotope can be used as a metaphor for the intrinsic value and aesthetic connectedness of temporal and spatial relationships that are artistically expressed in images, forms, colours, lines, words and symbols. One can therefore say that visual images and iconic seeing are in nature chronotopic and therefore "spiritual-synthetic"; it combines parts into the beauty of a "whole picture", that what one can call an "aesthetic image". For this "aesthetic exercise" one needs creative imagination and ecstatic inspiration: the birth of poetic beauty framed by a spiritual approach to life. supersede the dualistic split between sacred and profane, transcendence and immanence. For such a chronotypeapproach in life, one needs imagination, an aesthetic gaze that creates meaning, a kind of spiritual fusion, signifying the signs observed by the phenomenological gaze.

Al Gore in The Future Six Drivers of Global Change (2013), advocates for the reshaping of market capitalism and representative democracy. It is his conviction that this is possible by means of a new understanding of transcendence as a kind of 'spiritual fusion': the so-called 'Global Mind' (2013:369). The spirituality of the internet offers a welcome opportunity to reverse the degradation of democracy and the reestablishment of healthy self-governance (Gore 2013: 370). Digital information and 'Big Data' (Gore 2013: 55) are the drivers of renewal and the establishment of human dignity. "Still, the best chance for success in shaping a positive future and avoiding catastrophe is the reestablishment of a transcendent capacity for global leadership by the United States" (Gore 2013: 366).

It was the computer genius Steve Jobs, who has changed the whole face of technological digitalisation by introducing aesthetics to the computer business. He combined his slogan "Let's make a dent in the universe" (Blumenthal 2012: 93) with the aesthetics and art of design. While his youth companion Steve Wozniak could see "a sonnet in a circuit", Jobs, by contrast, could look at a beige box and see beauty (Blumenthal 2012:80). "He imagined a computer that was graceful and elegant as it was useful, an intersection of technology and art that resulted in something truly special" (Blumenthal 2012: 80). Steve Jobs changes a possible bankrupt company, Apple, into a financial miracle. The secret? He stayed true to his original vision for Apple: He believed there was room for beauty and art amid technology and commerce (Blumenthal 2012: 198).

Within the computer business and the pragmatic demands posed by man as homo faber (humankind as a producer of things; the making human being), Steve Jobs saw more. Jobs toyed with the 'idea of beauty' (homo aestheticus: man as the creator of beauty). For Jobs, the computer became an object of art with 'spiritual value'; even computers can contribute to a kind of aesthetic, spiritual fusion of life.

\section{Poetic seeing and the fantasy of aesthetic imagination (the beautification of life)}

In the publication Wie Kunst die Welt erschuf, Nigel Spivey (2006: 14) asserts that art is not merely the ability to craft (Handwerkliches Können); nor the endeavour to just beautify. Art emerges from the dynamics between human's creative ability and imagination/fantasy. The explosion of creativity in art is a mode of signifying life (Spivey 2006: 24). Serious art presupposes a kind of spiritual beauty; that what one can call 'creative integrity'.

According to Thomas Aquinas, integrity (integritas), harmony (consonanta) and clarity (claritas) can be described as the principles of beauty. They can also be interpreted as wholeness, proportion and luminosity (Skawran 2012: 3). The poetic question and the quest for beauty kindles a quest 
for congruency between viewer and an object. Within this dynamics, aesthetics can be described as the attempt to move images into the realm of imagination (Botha 2012: 5).

With reference to the art of Salvador Dalí (Miller at al. 2012: 34), the following remark underlines the connection between art, imagination and fantasy: "One should never forget, that one is moving in the realm of fantasy, of the stream of consciousness, of dreaming reason, in short, where art becomes life and life becomes art".

The aesthetic realism of the South African artist Paul Emsley, can be viewed as an attempt to transform the object or image into the realm of the imagination, framed by the subtle interplay between fantasy, light and shadow. Art is a 'spiritual endeavour' when the object emerges from the darkness of nothingness: creatio ex nihilo.

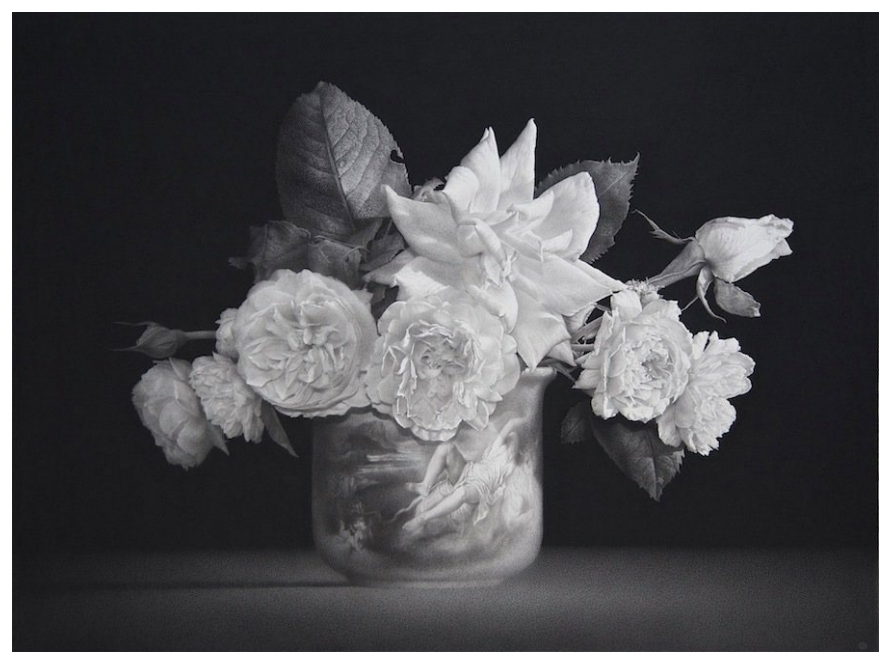

Europa 2011 by the South African artist Paul Emsley. "The object matter is the visible end of space" (Botha 2012:6) ${ }^{7}$. One starts to 'see' as the artist moves the object by means of imagination from the darkness of 'nothingness' into the light of aesthetics; art as creatio ex nihilo (permission from artist).

The question about "beauty" and aesthetics can also be linked to the qualitative question about vision, imagination, perspective, norms, values, convictions, culture and worldviews. It is not in the first place about the moral question regarding what is right and what is wrong. In essence, ethics and morality do not frame and demarcate the basic principles for 'beauty'. The question: what is beautiful? is more fundamental than the question: what is good? Why?

7 Online:http://www.google.co.za/imgres?q=paul+emsley\&start $=96 \& \mathrm{hl}=\mathrm{af} \& \mathrm{sa}=\mathrm{G} \& \mathrm{gbv}=2 \& \mathrm{tbm}=\mathrm{isch} \& \mathrm{tbnid}=\mathrm{MHXtMiBlF}-$ WLpQM:\&imgrefurl=http://paulemsley.com/\&docid=MohHlviNz_ dDZM\&imgurl=http://paulemsley.com/wp-content/gallery/ cache/117_900x663_dsc3187_3.jpg \&w=900\&h=663\&ei=8DRT T8ePDc-2hAf3ofWCDA\&zoom =1\&iact=hc\&vpx $=771 \& v p y=2$ \&dur $=8703 \&$ hovh $=193 \&$ hovw $=262 \& \mathrm{tx}=141 \& \mathrm{ty}=174 \& \operatorname{sig}=10$ $2009548252048832704 \&$ page $=7 \&$ tbnh $=145 \&$ tbnw $=140 \&$ nd $\mathrm{sp}=16 \&$ ved $=1 \mathrm{t}: 429, \mathrm{r}: 10, \mathrm{~s}: 96 \& \mathrm{biw}=1080 \& \mathrm{bih}=489$. Accessed:04/03.2012
Because the aesthetic question reveals an understanding of truth.

Oscar Wilde (in Botha 2012:5) once described aestheticism as a search after the signs of the beautiful through which men seek the correlation of the arts. Art is therefore the imaginative attempt to probe into the secret of life and the spiritual fibre of the human "soul". Art penetrates the soulfulness of life and could, thus, be rendered as the aesthetic attempt to probe into the realm of beauty. Beauty corresponds with the quest for integrity, meaning and purposefulness; it is an attempt to transcend transience into the direction of the sublime.

\section{The iconic view in sfumato: probing into the 'idea' beyond the ridiculous and the frailty and transience of life}

Imaging is to 'see' more. An iconic view probes into the 'idea' within and behind the object. In imaging imagination starts to guess, to suspect some-thing more; imaging toys with probability and creates something different; something that supersedes the senses. True imaging does what the Italians call 'sfumato' - "the blurred outline and mellowed colours that allow one form to merge with another and always leave something to our imagination" (Gombrich 2006: 228).

Imaging idealises. "Artists tried to modify nature according the idea of beauty they had formed when looking at classical statues - they 'idealized' the model" (Gombrich 2006: 244).

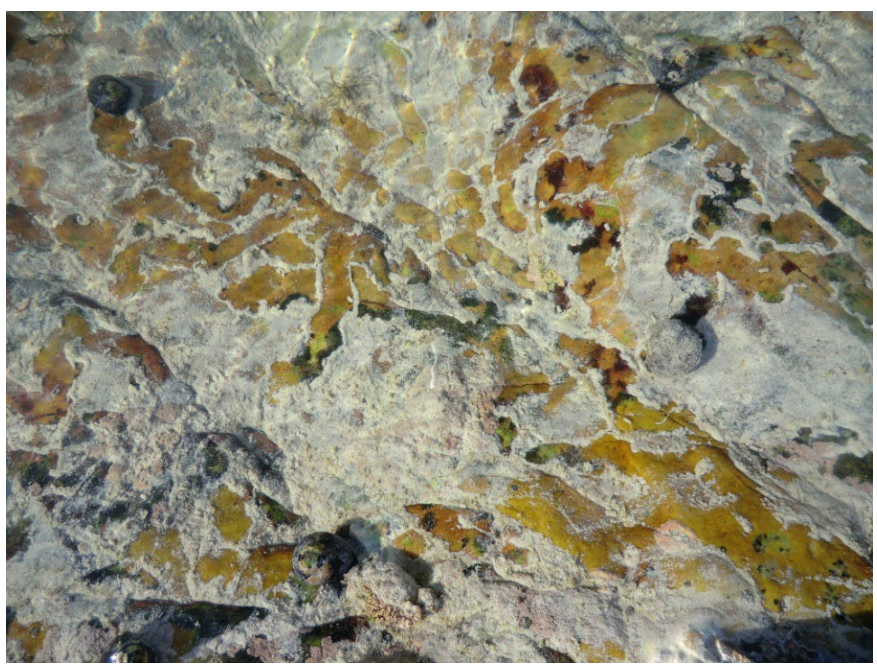

‘Sfumato by sea periwinkles. Photo D. J. Louw.

True imaging does what the Italians call 'sfumato' - "the blurred outline and mellowed colours that allow one form to merge with another and always leave something to our imagination" (Gombrich 2006: 228). The photo poses the question: what do I see? The challenge to the viewer is to interpret and to discover the spirit in the signs. The tracks (chiffre) left behind by the moving Periwinkles then become "alive" again.

But what is meant by the 'idea of beauty'? Can life be beautiful when one is painfully aware of the horrors of life and the existential reality of suffering and death? 
Aesthetics at the brink of death and the hell of slums: horrific scream or dazzling exclamation mark?

Aesthetics is amplified by the awareness of mortality and the acceptance of death. Aesthetics and imagination therefore cannot avoid the reality of a kind of existential anxiety: the fear for death, loss and rejection.

Maddi (2012: 69) points out that besides a kind of ontological anxiety about our future; the most severe existential sickness is vegetativeness. At a cognitive level, individuals, suffering from vegetativeness, cannot find anything they are doing or can imagine doing that seems interesting or worthwhile. "At the emotional level, vegetativeness involves a continuing state of apathy and boredom, punctuated by periods of depression that becomes less frequent as the disorder is prolonged" (Maddi 2012: 69). Another existential sickness is nihilism. At the cognitive level, the nihilist can find meaning only by disconfirming anything that purports to have positive meaning. The most hidden and masked form of meaninglessness is adventurousness in which some basis for positive meaning remains, but only through extreme risk activities while facing death. "At the cognitive level, everyday life seems empty, with vitality and importance reserved only for extreme, uncommon experiences" (Maddi 2012: 69).

For Salvador Dalí the creativity of aesthetics is closely related to the awareness of death, thus the quest in art to transcend the realm of death and transcience. The duality death (thanatos) and sensuality (eros) are the two companions of the poetic event. "The two motors that which drive the superfine artistic mind of Salvador Dalí are first, the libido or sexual instinct, and second, the fear of death. According to Dalí not a single minute of his life passes without the sublime, Catholic, apostolic, Roman spectre of death accompanying even the least of his highly subtle and capricious fantasies" (Néret 2007: 47).

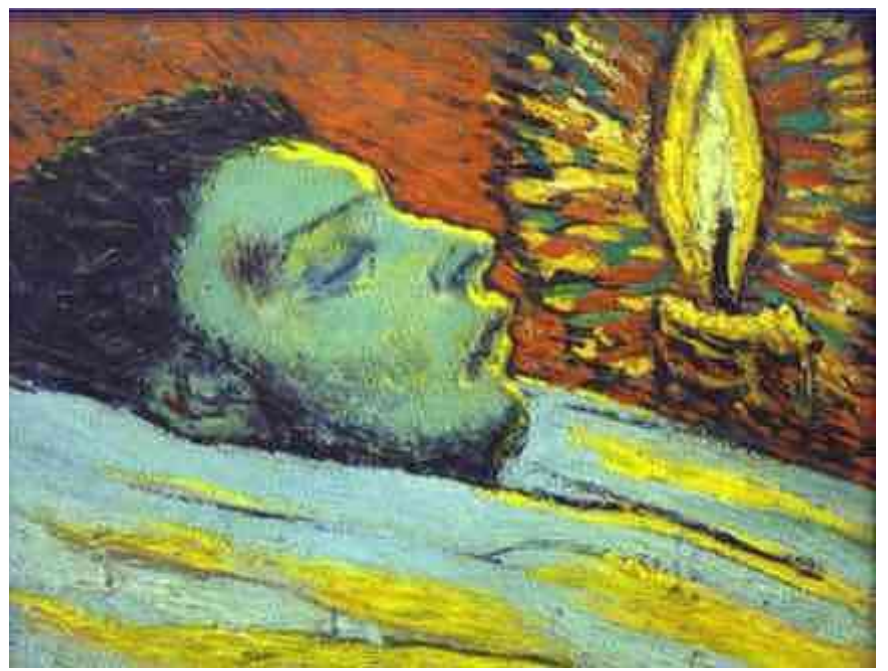

Pablo Picasso: The Death of Casagemas $1901^{8}$. The depiction captures the space of death with its total silence in a very poignant way. It is actually a kind of parody on Shakespeare's remark: "The way to dusty death. Out, out brief candle! (Macbeth).

"There is only one path out of the steamy dense jungle where the battle is fought over glory and power and advantage - one escape from the snares and obstacles you yourself have set up. And that is - to accept death" (Hammarskjöld 1993:7).

The encounter with death is the most realistic challenge of life.

“Tomorrow we shall meet,

Death and I-

And he shall thrust his sword

Into one who is wide awake" (Hammarskjöld 1993: 2).

Death brings about the imperative of seeing the unseen; it kindles a kind of yearning for transcendence, and, thus, introduces the aesthetic principle. All forms of life are surrounded by the framework of death. Death is, so to speak, the landscape of the human soul. Not in the first place, to threaten us with non-sense, but to challenge us with the quest for meaning. Death is like impressionism in art. Put next to yellow, blue and you "see" green. Put next to death, life, and you start to "see" the unseen and to decipher signals of transcendence.

From the viewpoint of "documentation" and "scientific verification" one should indeed confirm and say: Seeing is believing. Life is a catastrophe.

With reference to the now famous painting of Eduard Munch, life is a loud and horrified scream (Norwegian: skrik).

But, is life merely a skrik (dread and horror)? Is another perception not possible? Can life be beautiful and eventually become an exclamation mark (!) as well? What then is the meaning in life?

\section{What makes life worth living? The human quest for meaning, healing and wholeness}

It is the conviction of Wong (2012: 19) that the 21st century may

8 Online: http://www.google.co.za/imgres?imgurl=http://www. join2day.net/abc/P/picasso/picasso7.JPG\&imgrefurl=http://www. abcgallery.com $/ \mathrm{P} /$ picasso $/$ picasso $\cdot . h$ tml\&usg=_go8Ax7wyWG$55 \mathrm{c}$ grfITfK $8 \mathrm{cyvBo}=\& \mathrm{~h}=328 \& \mathrm{w}=432 \& \mathrm{sz}=17 \& \mathrm{hl}=\mathrm{en} \& \mathrm{start}=0 \& \mathrm{zoo}$ $\mathrm{m}=1 \&$ tbnid $=\mathrm{aCXZxSjTdgruOM}: \&$ tbnh $=125 \&$ tbnw $=176 \&$ ei $=\mathrm{M} 2 \mathrm{gR}-$ TumTBMOi-gb3qoX1Dw\&prev=/search\%3Fq\%3Dpicasso\%2Bthe\%2Bdeath\%2Bof\%2Bcasagemas\%26hl\%3Den\%26biw\%3D1007\%26bih\%3D559\%26gbv\%3D2\%26tbm\%3Disch\&itbs=1 \&iact $=$ hc $\& v p x=141 \& v p y=73 \&$ dur $=266 \&$ hovh $=196 \&$ hovw $=258 \& \mathrm{tx}-$ $=178 \&$ ty=125\&page $=1 \&$ ndsp=13\&ved=1t:429,r:0,s:0. Accessed: 05/07/2011. Public domain. 
be called a century of meaning in which people are struggling to recover a sense of meaning and purpose in the midst of international terrorism and the global financial meltdown. "The creation of a new world order and a more cooperative and humane society will demand a grassroots campaign to educate people about the importance of responsible and purposeful living" (Wong 2012: 19).

The question "What makes life meaningful?" is probably the most important question ever asked because it is vitally related to human survival and flourishing (Wong 2012: 3). The fulfilment of life revolves around the will to meaning and the creative principle of inspiration, imagination and purposeful motivation. The attributes of intentionality and purpose are the core of meaning (Klinger 2012: 23).

Apparently, meaning within the framework of a culture of entertainment, leisure and affluent wealth, art becomes closely related to happiness and pleasure. Research pointed out that people want to live a life of pleasure, engagement and meaning in order to live a real 'happy life'. However, happiness cannot be separated from the 'spirituality of aesthetics'. "Based on numerous studies, I have found that the worthy life consisted of the following components: happiness, achievement, relationship, intimacy, religion, altruism, self-acceptance, and fair treatment" (Wong 2012: 4).

Without any doubt, meaning in life depends on purpose, efficacy, value, and self-worth. These issues can directly be connected to belief systems and people's philosophy in life (worldview). All people possess a philosophy in life that is connected to culture. We all live by assumptions, beliefs, values, and worldviews that help us make sense of our lives. For example, capitalism and a market-driven economy will contribute to a happiness mind-set that values income and possession as most important for subjective well-being. Hedonism will focus on instant positive experiences and emotional equilibrium. According to Aristotle, a eudaimonistic philosophy is conducive to a meaning mind-set that considers virtue as the key to flourishing (in Wong 2012: 5).

In a nutshell, one can say that the four ingredients that define meaning are: purpose, understanding, responsible action and enjoyment or evaluation (Wong 2012: 10). I would like to add another three: vision, imagination and hope (the anticipation of constructive change in future that will make a difference in terms of existing difficulties: pro-spection and trans-spection). The hermeneutics of meaning is deeply attached to the creativity of future orientation and constructive anticipation; aesthetics is thus a 'proleptic enterprise'; it fuels creative alternatives for future orientation, vision and a hermeneutics of anticipation.

\section{Meaning and the art of interpretation}

In terms of hermeneutics, meaning is about the art of interpretation and the attempt to comprehend our experience. "Meaning is the web of connections, understanding, and interpretations that help us comprehend our experience and formulate plans directing our energies to the achievement of our desired future. Meaning provides us with the sense that our lives matter, that they make sense, and that they are more than the sum of our seconds, days, and years" (Steger 2012: 165).

This "more than the sum of...." is understood mostly in terms of the cognitive component in comprehension. However, it is argued that comprehension is fundamentally a spiritual category; it is an attempt to probe into the "idea' or "image" behind the object. Iconic viewing supersedes even the rationality of cognitive comprehension by means of imagination and symbolisation.

The act of meaning-giving is closely related to symbolisation. Meaning-giving can be described as the mental act of going beyond the specific characteristics of the phenomenology of experience and direct observation, by comprehending, categorising and interpreting them. In this regard, symbolisation and imagination play a vital role in the hermeneutics of meaning-giving and meaning-discovery. "Imagination is the mental act of combining and recombining categories of experience in a manner that goes beyond the literal ways in which they occur in the external world" (Maddi 2012: 57).

Both symbolisation and imagination imply judgement as the mental act of taking an evaluative stance with regard to literal or imagined experience. In this regard, metaphorical speech is needed in what one can call the hermeneutics of meaninggiving ${ }^{9}$. But meaning-giving implies more than symbolisation, imagination, wise decision-making and metaphorical speech. It also needs vision, i.e. the attempt to transform everyday experiences into images that deals with the unseen, spiritual dimension of life.

\section{Healing and the spiritual realm of life}

The realm of spirituality is becoming more acknowledged, even in the human sciences. Steger (2012:165-175) argues that psychological well-being cannot ignore spirituality, i.e. the general sense of transcendence and connection with something larger than one's self (Steger 2012:175). Spirituality can thus be identified and described as the pursuit of significance in that which is sacred about life (Steger 2012:175).

Even from the viewpoint of sociology, there is an attempt to re-evaluate the impact of the concept of "spirituality" on life and existential issues. A. Giordan (2007: 162) points out that spirituality is not anymore accessed according to its religious and traditional theological meaning. "Somehow, 'spirituality' has moved from the shadowy realms of theology to become

9 It is acknowledged by existential psychology that within the human quest for meaning, symbolisation, imagination and constructive or informed decision-making (judgement and wisdom) are constituents of psychological well-being, i.e. the eudaimonic principle of wellbeing. The latter focuses on fully flourishing and achieving one's potential as a human being (Steger 2012:165) (the inner-potential need-satisfaction theory). Meaning in life is then closely related to the level of personal need-satisfaction and the fulfilment of the dream: everything should work out to my advantage and to individual wellbeing (the eudaimonic principle). 
a 'fashionable' sociological concept". What happened in our contemporary society is the "democratisation of the sacred". The principle consequence of the democratisation of the sacred is that spirituality is used in sociology to refer to the realm of meaningful relationships and the fostering of human dignity. The individual, in his or her search for meaning, no longer accepts pre-packaged external norms. "Contemporary beliefs are not functioning regarding religious identity, which was created according to the criteria of stability. Instead they focus on experience rather than on dogma, on subjective personal authenticity rather than on objective truth; this perspective legitimises change as normal rather than exceptional" (Giordan 2007:171). According to Toffanello (in Giordan 2007:167), Christian spirituality can be significant today if it matches individual needs and is committed to improving the quality of life.

Adrian Andreescu, in his psychological research regarding the value of prayer in processes of healing (2011:23-47), is convinced that spirituality (the transpersonal realm of life) contributes to healing and well-being. He refers to the notion of "transpersonal capital". Healing also comes from outside and is not limited by internal sources. "I suggest that acquiring transpersonal capital requires at a primary level a conscious individual effort to inhabit and maintain a credible spiritual worldview, found to be largely congruent with the person's own mediated and unmediated life experiences" (Andreescu 2011:31). Healing is thus closely related to the credibility and appropriateness of life views.

\section{The significance of beauty in healing and the attraction of the unseen}

The movie Life Is Beautiful (La vita è bella) is a 1997 Italian film which tells the story of a Jewish Italian, Guido Orefice (played by Roberto Benigni, who also directed and co-wrote the film), who must employ his fertile imagination to help his family during their internment in a Nazi concentration camp. His wife Dora was in a different camp. One night he managed to play Barcarolle from the Tales of Hoffmann through the speakers. From the distance Dora heard the tune. She realized it was a "beautiful" message from Guido - the aesthetics of what you don't see, despite the horror of concentration camp transformed nonsense into significance and created a sense of spiritual wholeness.

In his autobiography, the German theologian Jürgen Moltmann, wrote about his experience as a prisoner of war (1945-47): "War stories are not tales of adventure. They are stories about destruction and death" (Moltmann 2008:19). He recalls how they sat in the trenches and "cracked" lice, which proliferated more quickly than they could kill them. And one day, when he was nearly at the brink of despair, while they were pushing a goods truck, he suddenly stood in front of a blossoming cherry tree. "I almost fainted with the joy of it. After a long period of blindness without any interest, I saw colours again and sensed life in myself once more. Life began to blossom afresh" (Moltmann 2008:27). The aesthetics of a blossoming cherry tree become an icon of hope.
Viktor Frankl wrote about his experiences in a concentration camp. He awoke from the sleep of exhaustion on his second night in Auschwitz. He was roused by music. "Suddenly there was a silence and into the night a violin sang a desperately sad tango...The violin wept and part of me wept with it, for on that same day someone had a twenty-fourth birthday. That someone laid in another part of the Auschwitz camp, possible only a few hundred or a thousand yards away and yet out of reach. That someone was my wife" (1963: 27).

The aesthetics of music superseded the limitations of horror; aesthetics makes transcendence possible where all reason to anticipate something different or new became impossible. Aesthetics creates a sense of spiritual wholeness despite the horror of the concentration camp and the smells of death, dying and destruction.

In her Diary, Anne Frank calls this possibility to transcend the ugliness of reality by the imagination of something beautiful, the art of life. To imagine that the inedible food in her plate was nice, she managed to cope with the reality of hunger (2008: 150). Beauty distorts, twists ugliness.

\section{'Baroque catholicism' and the hell of slums: the grassroots question}

For poor people living in ugly townships at the outskirts of cities, the basic question is how to survive on a daily basis without losing one's human dignity. Zanotelli, in the publication The Slums (2002: 13-15), describes the slums of Nairobi as the hell of life. The slums are usually placed below the sewer line. Within a context of severe poverty, even before you dare to pose the question regarding human dignity, you first need to wash away your materialism, rationalism and 'baroque catholicism' (Zanotelli 2002:15). The next step is to descend into the hell of the slums; you need to undergo the baptism of the poor in order to talk about dignity. "You learn to read things upside down. Your worldview, your theology, even your morality, just goes to pieces. When I try to dissuade young girls from going to town for prostitution, they tell me there is no other way to survive.' But you are sure to meet Aids!' I insist, 'It's OK! Die of Aids or die of hunger, what's the difference? Or maybe there is! You have a chance of longer life with Aids'. I understood that what I held as morality is, to a large extent, middle class morality".

In Africa, at the grassroots level, life is normally determined by bread and butter questions. The reality of famine and existential suffering caused by HIV and AIDS determines the quality of life, not necessarily art and icons.

However, a recent personal experience in a remote and poor Masai village in Tanzania, made me aware of the appropriateness of an "iconic view" on life and how life can become beautiful within environments of severe poverty. I was privileged to attend the inauguration of a water tank, in the village of Emeshiye. It was donated to the people of this village by a Lutheran group of congregations in Germany. In the past people, mostly women and children, have to walk long distances to fetch water for daily use. An old woman of the village was asked to open the tap. She put a plastic bucket under 
the running water. She then put the container on her head and, with a gesture of surprise, turned to the people. They started to celebrate, to dance, and to laugh. They were overwhelmed with joy and gratitude. Suddenly I became aware of a miracle in the desert; I "saw" how Moses hit the rock in the desert and how God provided water for Israel. The place where I stood became holy; the space around the tank was sacred; the Masai village was a sanctuary of worship. With this iconic view in mind, I think about the taps in my home in Stellenbosch South Africa. I usually open them and just take running water for granted. To turn the tap was never ever in my life "holy"; for me water is a formula $\mathrm{H}_{2} \mathrm{O}$, not a sacrament of divine provision.
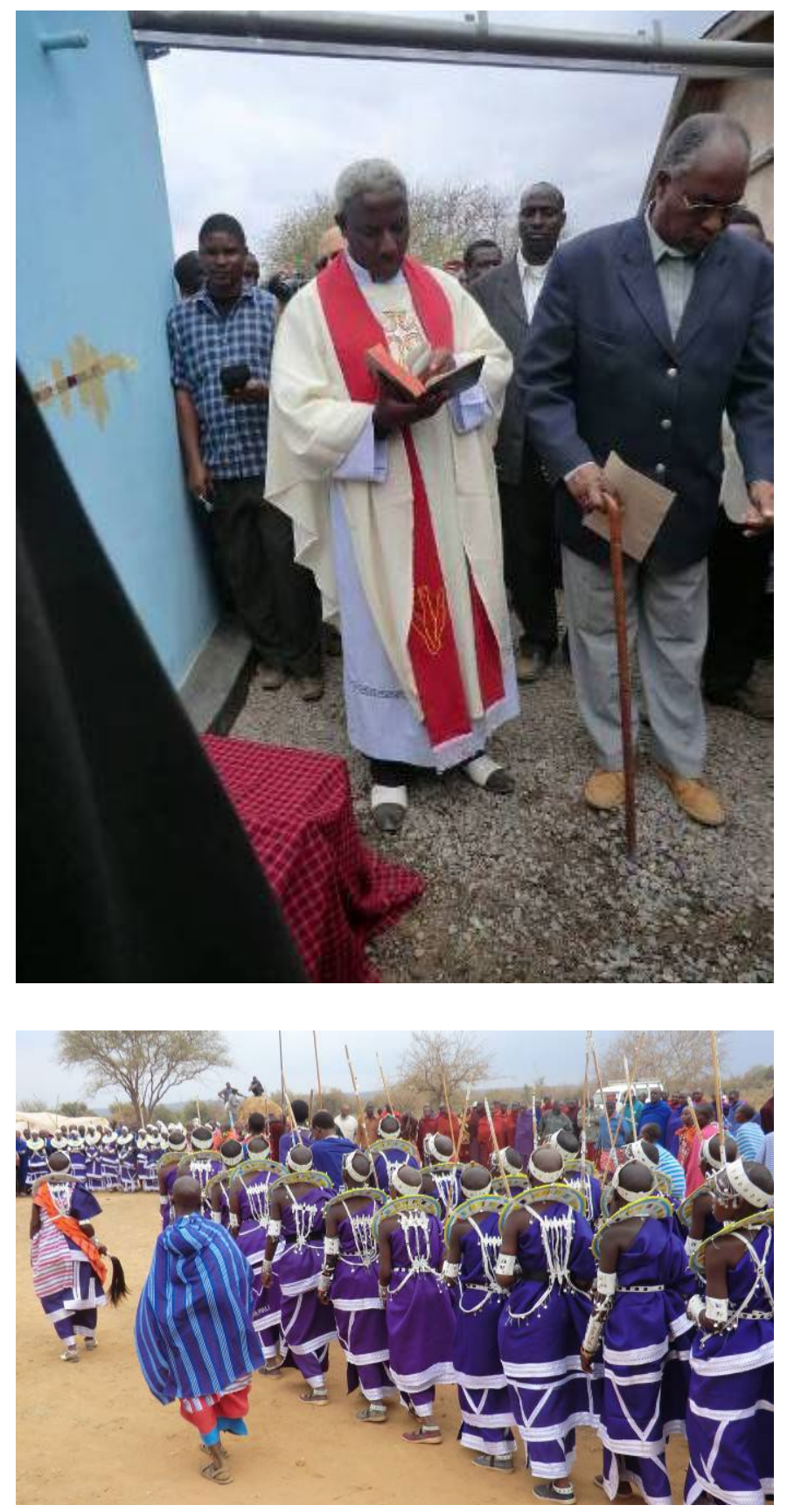

Massai village in Tanzania. Left: The inauguration of a water tank, in the village of Emeshiye. Right: Procession of women to the tank, dancing and singing. The Massai village became a sanctuary of worship, holy ground (photo: D.J. Louw, 2012)
The Massai-experience was beautiful. Back in South Africa the Maia-experience brought about a reframing of daily life. Due to an iconic view, I started to "see" life and the functionality of running water from a tap from the perspective of aesthetics. Gratitude is the first step into a sacramental stance on life; the water in a Massai reservoir became a sacrament, a symbol of transcendent grace and compassion (spiritual wholeness).

In the Massai-case, the ethics of providing a water tank opens up the aesthetics of spiritual seeing: to "see" the providence and 'presence' of God'.

Could aesthetics indeed be connected to religious imagination?

\section{Art as mode of religious, aesthetic expression?}

Art is for the practical theologian Wilhelm Gräb, a mode of religious based self-manifestation (2012: 15). Due to the inner power of aesthetics on human self-awareness, art contributes to transcendent-experiences. In this regard, art can play a decisive role in the transformation of existing God-images. Inappropriate God-images contribute to religious pathology, while appropriate God-images promote spiritual healing and well-being (Utsch 2012:106).

The point is: what we call worldly, the saeculum, is more than brutal matter and raw factuality. The cosmos is deeply determined by an $\mathrm{x}$-factor. One can call it fate or providence or even the sublime. It does not matter. When we perceive and observe from the perspective of faith, we become aware of mystery, of a supernatural factor, of a kind of sacramental experience in which normal objects start to point to the transcendent realm of life. Matter attains a kind of translucent meaning; it reveals the aesthetics of creation.

In fact, one is often suddenly overwhelmed by the unseen and a sacred "illumination". This experience can be called the surprise of amazement. It is as if some-"thing" unreal, supersedes the senses and the rationality of the mind. This surprise stirs up an awareness that life is not about a void nothingness; there is indeed sense in nonsense, significance despite the impression of nihilism. Nietzsche, who has wrongly been called the father of nihilism, referred to this moment of existential surprise, as a moment of poetic inspiration. "One is seized by an ecstasy" (Nietsche 19663:20). Ekstasis in Greek: to be outside the normal state; a kind of spiritual "out-of-body experience" (Penthcheva 2010:37).

\section{Towards a Socratic view of life}

With the aesthetics of the unseen and the emphasis on an iconic approach to life I am back to what one can call a Socratic view on life. Life entails more than the flat horizontal and empirical approach of sensory observation. Socrates wanted to penetrate the physical world by means of the notion of the goodness, the inherent beauty that contributed to the fact that things are as they are. In spite of a scientific explanation, he opted for an aesthetic option. "He is looking for explanations in terms of some ultimate Goodness which forms everything, including us, and draws us to it by means 
of spiritual knowledge and desire. We must consider not the things which Anaxagoras and the scientists speak of, but the real, ultimate causes of Beauty, Goodness, Magnitude, and so on, which the good and beautiful things and the quantities of things on earth participate in and reflect" (O'Hear 2007:108).

Aesthetics opens up a spiritual knowledge that helps to view the "soulfulness" in life; it detects the imperishable and brings reality to life. Therefore, one of the possible functions of aesthetics and the visual arts towards the rediscovery of the soulfulness of life, could be to open the eyes of secularised people, captured by materialistic need-satisfaction and the commercialised endeavour of money making, for the beauty inherent to matter and the spiritual dimension of the unseen.

In the early religion of the Romans, lifelike portraits were important. It was believed that likeness preserves the soul' (Gombrich 2006:95). Statues were not regarded as lifeless objects, but an attempt to capture the essence of being; an object should present 'soul'.

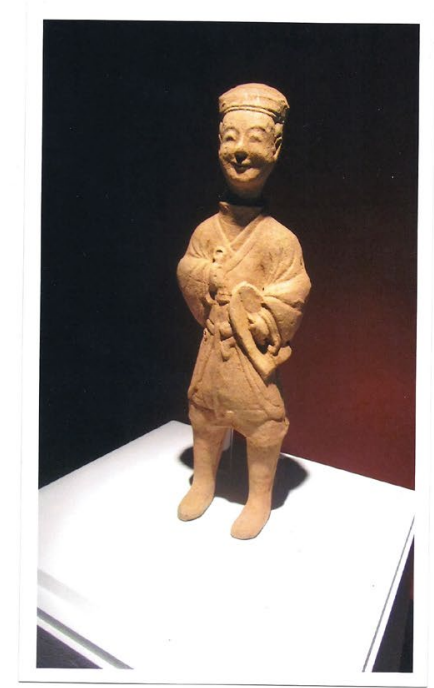

Remarkable ceramic smiling, sensual soldier. Han (206 BC - 220 Ad). Sichuan Chengtu Pottery (68 x 22 x 12cm). Private collection, Seoul, Southern Korea (photo D.J. Louw with permission from the artist). This is an excellent example of how the artist captured the 'soul' of the person. When compared with Egyptian art the statue is much more 'alive'.

It could indeed be the case that most people experience life as harsh, painful and ugly. In a world determined by the struggle to achieve, to produce, to work hard, to survive, to suffer and at the end, to die, the cynical conclusion should indeed be: life is meaningless and therefore without 'soul".

For Socrates, art should represent the 'workings of the soul' (Gombrich 2006:85). Due to sensuality and how feelings affect the body, iconic viewing can turn a simple tombstone into a great work of art. It was Greek art who turned marble into life.

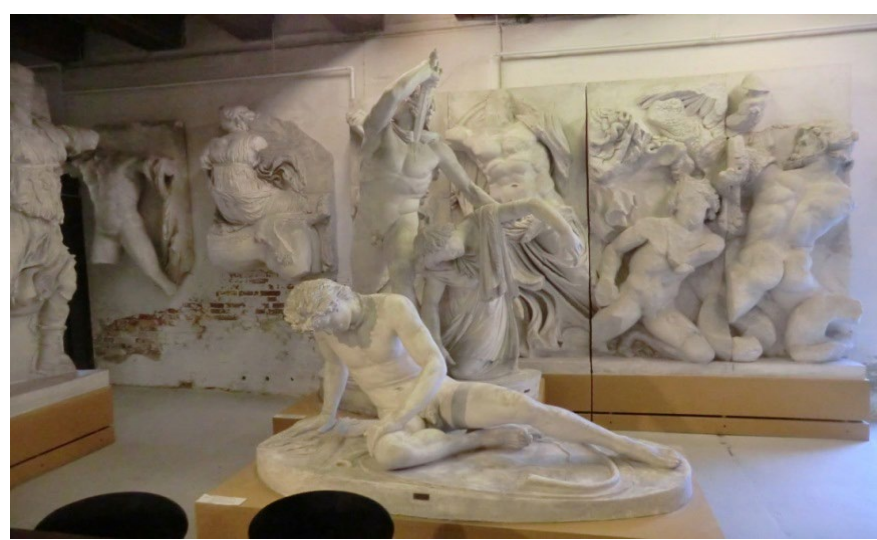

One can indeed concur with the assertion of Gombrich (2006:85) that Greek art turned marble into life (collection of casts from Greek sculptures, Royal Cast Museum, Copenhagen) (photo by D.J. Louw)

Statues started to present the 'inner life' of a figure and conveyed unspoken feelings making an appeal to the senses. Classical art therefore challenges the artist to capture the idea or essence of an object. This approach to aesthetics can be called the ontology of aesthetics; i.e. the attempt to wrestle in marble, clay or paint with the essence of being. Mostly this essence supersedes the vision in empirical observation. Art then tries to portray the soulfulness of life.

\section{Inspiration and the metaphysics of surrealistic seeing}

The urge to signify "the more", the yearning for "spirituality" beyond the limitations of reason and logic was well articulated by surrealism in the twenties of the previous century.

Rookmaker (1973:144) pointed out that the upcoming of surrealism in the early twenties, is an indication of a revolt against the structure of reason. "Their aim was a liberation of life, in every aspect, to free man from this strange world that holds him in a thousand ways; on the basis of Freudianism they wanted to liberate man from convention, culture and society. The third issue of La Révolution Surréaliste, asserts: 'Ideas, logic, order, Truth (with a capital T), Reason, all this is given to the nothingness of Death. You do not know how far the hatred we have against logic can lead us."

In essence, surrealism can be described as intrinsically a "religious" and "spiritual" act. Although atheism framed the worldview of many surrealists, Salvador described his art as a "new religion"; a kind of religion which probes into transcendence, but at the same time wants to be sadistic, masochistic, dreamlike and paranoiac (Descharnes \& Néret 2006:96). The reference to the so called Dalí delirium, becomes more understandable when one realizes that Dalís surrealism was about the quest for the archetype within the known objects of daily living (Descharnes \& Néret 2006:166). The strange mysticism of surrealism is for Dalí an entrance into the secret of reality. Surrealism is a kind of meta-physical, iconic seeing. Within an environment who became bored with time, he bended clocks into soft, weak, flaccid, objects in order to free human beings from the tyranny of time. 
Poetic inspiration and ecstasy are the aesthetic means by which a human being gets access to the mystical realm of the unseen. This is the reason why Salvador Dalí said:

I want to perceive and understand the hidden powers and laws of things, in order to have them in my power. A brilliant inspiration shows me that I have an unusual weapon at my disposal to help me penetrate to the core of reality: my mysticism - that is to say, the profound intuitive understanding of what is, direct communication with the all, absolute vision by the grace of truth, by the grace of God. More powerful than cyclotrons and cybernetic calculators, I can penetrate to the mysteries of the real in the moment...Mine the ecstasy! I cry. The ecstasy of God and Man. Mine the perfection, the beauty, that I might gaze into its eyes!" (Néret 2007:79).

The aesthetics of ecstasy is the creative power of artistic freedom and imagination.

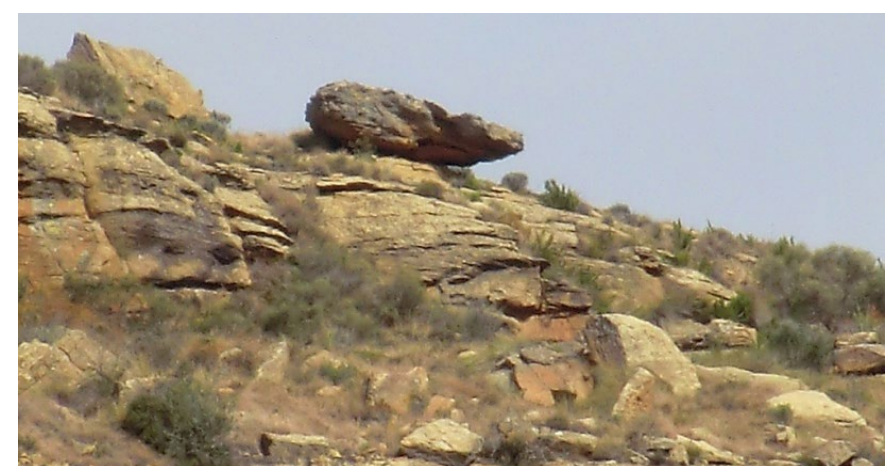

Surrealistic seeing by means of aesthetic creativity and imagination. "Prehistoric Rock Creature", Banghoek. Molteno Eastern Cape (photo by D.J. Louw).

"Everything is in the highest degree involuntary, but takes place as if in a tempest of freedom, of absoluteness, of power and divinity" (Nietsche 19663: 20). Inspiration is in itself then divine. It makes one enthusiastic, literally from the Greek: en-theos, God within us, within our very being.

\section{Playfulness and an iconic view ('visuel'): seeing the unseen}

One is often struck by awe and an uplifting experience of immense joy and fulfilment. It is as if empirical sensation is overwhelmed by glimpses of transcendence. Life becomes iconic and objects are transformed into peep-holes, depicting the mystery of the unknown and the spiritual realm of life. "By reviving Spanish mysticism, I, Dalí, shall use my work to demonstrate the unity of the universe, by showing the spirituality of all substance" (Néret 2007:79).

Dag Hammarskjöld (1993: 77) very aptly remarked: "A landscape can sing about God, a body about spirit". This cosmic singing and spiritual interpretation can be called an iconic vision and playful view on life.

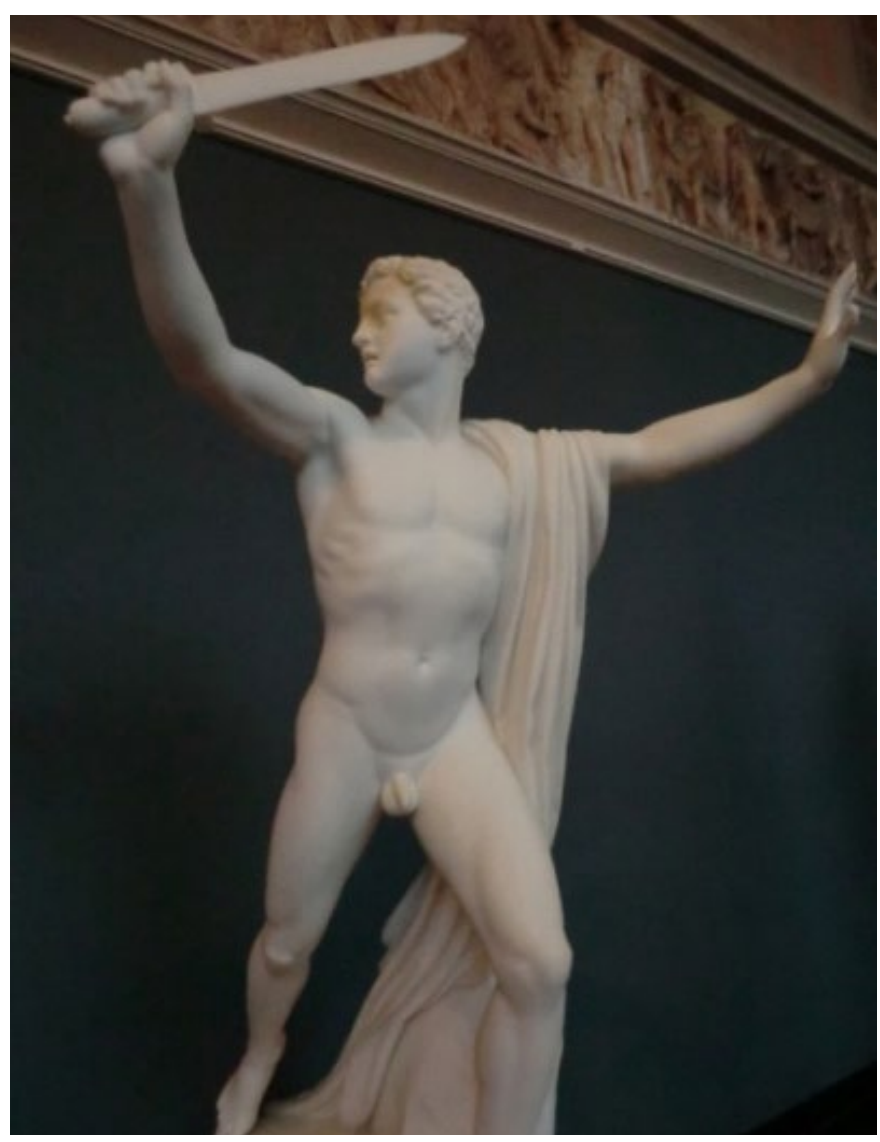

In this sculpture made by H. W. Bissen (1798-1868) (Orestes flees from Eumenides) the playful movement and beauty of the free male nude, captured what Dag Hammarskjöld called a body can sing about spirit. (Permission: NY Glyptotek, Copenhagen, photo by D.J. Louw)

The art of iconic seeing is to see with a spiritual gaze until one sees more: transcendence. In this regard the difference made by the French philosopher Georges Didi-Huberman between 'visuel' and 'visible' is most appropriate (in Cottin 2012: 143). 'Visible' is about what one sees, what is visible for the senses. The visible can easily become an idol. 'Visuel' is about probing into the Ultimate (Jenseits), 'visuel' sees by means of images and makes the invisible meaningful; it is a mode of signifying life in terms of transcendent-awarenesses. The 'visuel' operates by means of icons.

Within the sphere of the visual (and here I purposefully use "visual" as opposed to "visible", "performative" bears the marks of phenomenal: it refers to the spectacle of changing surfaces under perennially shifting ambient conditions. In focusing on the interaction between object and subject, between icon and viewer, between poetry seen and poetry pronounced. I uncover the power of the icon's spectacle to transform the viewer from observer to participant, communicating with the divine (Penthcheva 2010:3).

The visual dimension of an eikon functions as a revelation (making truth understandable and visual sensual, even sensible); a kind of epiphany (epiphaneia) (the manifestation of divine presence (supernatural being) manifested in visible form. 


\section{The loving gaze: the art of religious seeing}

The more of iconic seeing ('visuel') is about the spiritual art of imaging the unseen, even of seeing God. Christ himself is described as the image (eikōn) of the invisible God (Col. 1:15). The fact is that in Christ as the image of God we share in the reality of a divine presence indirectly by means of a faithful gaze. In Greek thought, an image shares in the reality of what it represents. The essence of the thing appears in the image, e.g. God is himself present and operative in his image (Flender 1976: 288). In wisdom thinking (sapientia), the access to this divine presence is an act of faith mediated by the Spirit of God.

In his book Seeing Things, Stephen Pattison sums up the predicament of people living in an age of what might be characterised as 'visual overload' or hyper-visuality: "we have so much, but see so little" (Pattison 2007: 1). We are living in a visual culture overloaded with images. Images rain upon us in all spheres of life. "With the extension of sight by microscopic, telescopic, electronic, digital and other means symbolised by instruments such as electron microscopes, scanners, cameras and photographs, we are all too aware of living in a world structured round sight and the visual" (Pattison 2007: 3).

"If the scopic regime of the 'arrogant eye' is to be rejected in favour of fostering more intimate fellowship with visual artefacts, then an alternative approach is required that allows the emergence of a more intimate, loving gaze" (Pattison 2007: 19). And in religion this loving gaze is closely related to an iconic view on life and an understanding of the 'beauty of God'.

\section{Religious aesthetics: divine compassion}

It was the so-called atheist Ludwig Feuerbach (1904) who already in the nineteenth century warned the church against the idol of a God with 'brains' without any passion and 'heart'. In chapter VI on the secret of the suffering of God (Das Geheimnis des leidende Gottes) (1904: 126-136), Feuerbach distinguished between the God of abstract philosophy, God as pure action, with the God of Christendom, God as pure passion, the God of pure suffering (die Passion pura, das reine Leiden) (Feuerbach 1904: 127). The suffering of God means: God is a heart (Gott ist ein Herz) (Feuerbach 1904: 131). A God without a heart is an idol. The secret of the suffering God is the secret of existential experience (Geheimnis der Empfindung; kontingente bevindelikheid). Suffering and passion then defines the beauty of God within the ugliness of death and destruction.

\section{The art of foolishness in religious thinking}

Campbell and Cilliers (2012:67-68), in their book on the art of preaching as the endeavour to distort the fixed conceptions in orthodox thinking, refer to Enid Welsford's notion that the art of foolishness implies an engagement of "melting the solidity of the world". Fools instigate and sustain liminality. "They break into our circled wagons and smelt down our iron theologies".

Can then an iconic view on a vulnerable and suffering God do the same? Is it possible for aesthetics to melt down the solidity of iron theologies and demolish the bunkers of ecclesiological imperialism in order to rediscover the aesthetics of both God and human beings? Alternatively, are we merely corrupted sinners, doomed to die?

\section{The 'ugliness' of a powerless God?}

The "Father Almighty" (God as pantokrator: the imperialism of threat power) developed under the influence of an affluent society into the romantic sentimentality of Father Christmas All-merciful. Instead of a suffering God, the triumphalism of a theology of glory "removed the cross from the heart of God" (Hall 1993: 96).

God is depicted as one who, unlike us, does not exist under the threat of nonbeing in any of its manifestations. Thus, the divine power (omnipotence) is not challenged by any lack or weakness; the divine knowledge (omniscience) is not circumscribed by ignorance, uncertainty, or inherent limitation; the divine presence (omnipresence) is not subject to the constraints of time and space; and God is not vulnerable to change or prey to passions that may be aroused by any existential eventuality (immutability) (Hall 1993:96-97).

Paul links God to the event of suffering and introduces the "weakness of God"; the logos of the cross (logos tou staurou). This notion of power is marked as "foolishness" (a variant of the aesthetic category of ugliness). The power of human beings (ousia) is challenged by the 'weakness of God' which is stronger than human strength (I Cor.1: 25). Why? Because it affirms God's identification with the vulnerability of suffering human beings. It opposes destructive domination and affirms constructive opposition. God becomes the helpless innocent victim of the Roman soldiers. The sacredness and divinity reside in the cry of protest (derilictio): "My God, My God why have you forsaken me?" With the act of forgiveness, Jesus as the icon (eikon) of God, not of Roman power, became an innocent and helpless victim of Roman imperialism.

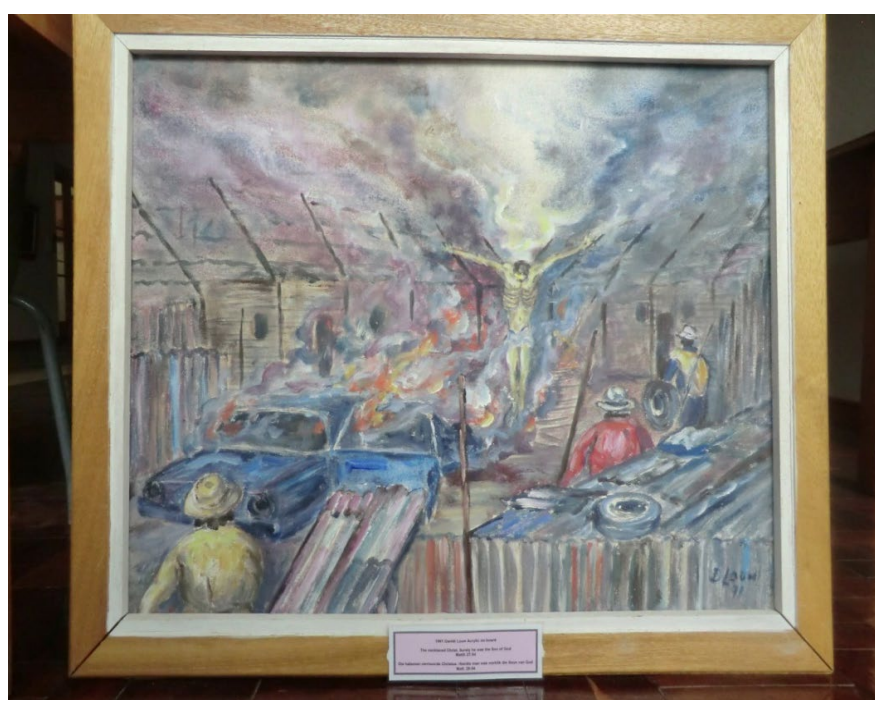

Crossroads, Cape Flats (Township Crucifixion). The necklaced Christ as victim of the Roman soldiers (Apartheid policymakers) within the hell of township life (D.J. Louw, 1991). In the painting the dying Son of God was killed by the injustice of all forms of oppressive imperialism. 


\section{Foolishness reframes God into "beauty" by means of sheer ugliness.}

God is not a cosmic force, a worldly power, a physical or metaphysical energy or power source that supplies energy to the world, who designs it, starts it up and keeps it going, and who occasionally intervenes here and there with strategic course corrections, a tsunami averted here, a cancerous tumour there, a bloody war quieted over there (Caputo 2007:65).

As Caputo argues, we should replace Christian icons of amor fati, fatalism, with Christian icons of amor venture (the loving gaze), a love of unconditional acceptance; love as a challenging venture with God, our covenantal Partner for Life.

\section{IN CONCLUSION}

Art operates on different levels; visual art represents indeed a dimension of entertainment and amusement (the pleasant experience of I-like-it). However, 'serious art' is the attempt to decipher 'signals of transcendence' by means of creativity, imagination and inspiration of poetic seeing. Visual arts in religious thinking should revisit the realm of spirituality and the human quest for healing and wholeness. In this regard, depictions of God in terms of human vulnerability, weakness, frailty and the abuse of power, can contribute to a theological attempt to move omni-categies (imperialistic impressions of threat power) into pathos-categories (theopaschitic portrayals of divine compassion).

\section{BIBLIOGRAPHY}

Andreescu, A., 2011, 'Rethinking Prayer and Health Research: An Exploratory Inquiry on Prayer's Psychological Dimension', International Journal of Transpersonal Studies, 30 (1-2), 23-47.

Antonova, C., 2010, Space, Time and Presence in the Icon. Seeing the world with the Eyes of God, Ashgate, Farnham.

Berger, P.L., 1992, A Far Glory: The Quest for Faith in an Age of Credulity, The Free Press, New York.

Blumenthal, K., 2012, Steve Jobs. The Man who thought Different, Bloomsbury, London.

Botha, A., 2012, Beauty and Truth: An Aesthetic Appreciation of Paul Emsley's Art. In: A Botha, Paul Emsley. US Woordfees/Wordfest Artist 2012. Retrospective Exhibition. Stellenbosch: Sasol Art Gallery, pp. 5-9.

Campbell, L. \& Cilliers, J.H., 2012, Preaching Fools. The Gospel as a Rhetoric Folly, Baylor University Press, Waco.

Caputo, J.D., 2007, Spectral Hermeneutics. On the Weakness of God and the Theology of the Event. In: J. D. Caputo, G Vattimo, After the Death of God. Columbia Press, New York.

Clare, A., 2000, On Men: Masculinity in Crisis, Chatto \& Windus, London.

Cottin, J., 2012, Die Aufname der visuellen Dimension in der Biblische Hermeneutik am Beispiel von Paul Beauchamp and Paul Ricoer. In: W. Gräb, J. Cottin (Hrsg.), Religion - Ästhetik - Medien. Theologische, psychologische und ästhetische Reflexionen zur spirituellen Dimension der Kunst. Band 3. Franfurt am Main: Peter Lang, pp. 140-156.

Descharnes, R.G. Néret, 2006, Salvador Dalí. 1904-1989. Taschen, Köln.

Dissanyake, E. 1992. Homo Aestheticus: Where Art comes from and Why, Free Press, New York.

Feuerbach, L., 1904, Das Wesen des Christentums, Verlag Philipp Reclam, Leipzig

Frank, A., 2008, Die Agterhuis, Protea Boekhuis, Pretoria.

Frankl, V., 1963, Man's Search for Meaning, Pocket Books, New York.

Flender, O., 1976, Eikōn In: C. Brown, Dictionary of New Testament Theology, Vol.2, Paternoster Press, Exeter.

Giordan, G., 2007, Spirituality: From a religious Concept to a Sociological Theory. In: K. Flanagan, P. C. Jupp (eds.), A Sociology of Spirituality. Aldershot, Ashgate.

Gombrich, E.H., 2006, The Story of Art, Phaidon Press, London.

Gore, A., 2013, The Future Six Drivers of Global Change, Random House, New York.

Gräb, W., 2012, Kann die zeitgenössische Kunst Gott verkündigen? Die Schreiter-Fenster in St. Jakobi in Göttingen. In: W. Gräb, J. Cottin (Hrsg.), Religion - Ästhetik - Medien. Theologische, psychologische und ästhetische Reflexionen zur spirituellen Dimension der Kunst. Band 3, Peter Lang, Frankfurt am Main.

Hammarskjöld, D., 1993, Markings, Ballantine Books, New York.

Huyghe, R., 1981, Art Forms and Society, In: R. Huyge (ed.) Larousse Encyclopedia of Byzantine and Medieval Art. Art and Mankind, Hamlyn, London.

Jaspers, K.,1962, Der Philosophische Glaube angesichts der Offenbarung, Piper Verlag, München.

Klinger, E., 2012, The Search for Meaning in Evolutionary Goal-Theory Perspective and Its Clinical Implications, In P.T.P. Wong (ed.), The Human Quest for Meaning. Theories, Research, and Applications, Routledge, New York/London. 
Maddi, S.R., 2012, Creating Meaning through Making Decisions, In P.T.P. Wong (ed.), The Human Quest for Meaning. Theories, Research, and Applications, Routledge New York/London.

Miller, C., Ess, H., Glökner, S., Kollmeier, C., 2012, Dalí. Die Ausstellung am Potsdammer Platz, Dalí Berlin Ausstellungsbetriebs-GmbH, Berlin.

Moltmann, J., 2008, A broad Place. An Autobiography, Fortress Press, Minneapolis.

Néret, G., 2007, Salvador Dalí. 1904-1989. Conquest of the Irrational, Taschen, Köln.

Nietzsche, F., $1966^{3}$, Thus spoke Zarathustra, Penguin, Harmondsworth.

O'Hear, A., 2007, The Great Books. From the Iliad and the Odyssey to Goethe's Faust: a Journey through 2,500 Years of the West's Classic Literature, Icon Books, Cambridge.

Pappalardo, U.R., Ciardello, 2012, Griechische und Römische Mosaiken, Hirmer Verlag, München.

Pattison, S., 2007, Seeing Things. Deepening Relations with Visual Artefacts, SCM Press, London.

Pentcheva, Bissera V., 2010, The Sensual Icon. Space, Ritual and the Senses in Byzantium, The Pennsylvania State University Press, University Park, Pennsylvania.

Rookmaker, H.R., 1973, Modern Art and the Death of a Culture, Inter-Varity Press, London.

Skawran, K.M., 2012, Integritas, Consonanta e Claritas. Reflections on Selected Sculptures and "Drawings with Colour", In: Willem Strydom, Stellenbosch: Rupert Museum, pp.3-15.

Spivey, N., 2006, Wie Kunst die Welt erschuf, BBC Books, Stuttgart.

Steger, M.F., 2012, Experiencing Meaning in Life. Optimal Functioning at the Nexus of Well-being, Psychopathology, and Spirituality, In P.T.P. Wong (ed.), The Human Quest for Meaning. Theories, Research, and Applications, Routledge, New York/London.

Wong, P.T.P., 2012, Toward a Dual-Systems Model of What Makes Life Worth Living, In P.T.P. Wong (ed.), The Human Quest for Meaning. Theories, Research, and Applications, Routledge, New York/London.

Zanotelli, A., 2002, A Grace Freely Given. In: P. Francesco, Y Abeledo (eds.), The Slums: A Challenge to Evangelization, Pauline Publications, Nairobi.

\section{ACKNOWLEDGEMENTS}

\section{Competing interests}

The author declares that he has no financial or personal relationship(s) that may have inappropriately influenced him in writing this article. 